\title{
NOTABLE MODIFICATIONS OF SUSHRUT SAMHITA BY DALHANA
}

\author{
Review article
}

\author{
Kanchan M Borkar $^{1 *}$, Anantkumar V. Shekokar ${ }^{2}$ \\ 1. Lecturer, 2. Reader and HOD, \\ Dept.of Shalya-Tantra,S.V.N.H. Ayurved College, Rahuri.
}

\begin{abstract}
Sushruta, the father of surgery gave Sushrut Samhita to his followers. The Sushrut Samhita gives simple, precise, logical and practical knowledge. Available commentary on Sushrut Samhita is Nibandhasangraha which is written by Dalhana who gave reasoning and description about some unsolved puzzles in Sushrut Samhita. This commentary is available in Sanskrit language which is unrecognized by common Ayurveda scholars and researchers. Although it is very difficult to understand and translate the Samhita in an easy language it will be a boon to all the Ayurveda scholars if we can understand the Dalhan's explanation of Sushruta's view. In this article we shall try to understand and interpret the knowledge of Sushruta and Dalhana from Sutrasthan Adhyaya no. 1 to 10 in parallel to western surgical knowledge to get a better understanding of basic principles of ancient and western surgical practice.
\end{abstract}

Keywords: Sushrut Samhita, Nibandhasangraha, Shalya, Mala, Vrana, Shadvidh Pariksha.

\section{Introduction}

Sushruta is the father of surgery and the greatest surgeon of ancient period. He had kept a sea of surgical knowledge in the form of Sushrut Samhita to his followers. Sushrut Samhita, which describes the ancient tradition of surgery in Indian medicine is considered as one of the most brilliant gems in Indian medical literature. This treatise contains detailed descriptions of teaching and practice of the great ancient surgeon Sushruta which has considerable surgical relevance even today. Sushrut Samhita, contains major surgical text of Veda's and is considered to be the most advance literature of surgical practices of its time. It is a simple,

\footnotetext{
*Corresponding Author:

Kanchan M Borkar, Department of Shalya Tantra, S.V.N.H.Ayurved college, Rahuri. Maharashtra, India.- 413706 Email: drkanchanborkar@gmail.com Ph.No: +91 9960299306
}

easily understandable, logical and practically useful literature. Many commentaries are written on Sushrut Samhita by different commentators. Out of which some are available partially and some are not. Only Dalhana's Nibandhasangraha is completely available today.

Dalhana was the follower of Sushrut Samhita who was having detailed knowledge of multiple sciences. He added cream knowledge of other Samhita's in his commentary. Nibandhasangraha is an elaborate description of precepts and practices of surgical tradition known at their time. He furnishes quotation from many other treatise on surgery and therefore both academically and historically significant. He had detailed knowledge about Sanskrit language and was on the topmost position in surgical profession at that time. Dalhana's commentary Nibandhasangraha has not seen the light of day till date. It is used by only a few research workers and some 
philosophers and very rarely used by a common scholar of Ayurveda. This commentary, therefore is not in the limelight due to the Sanskrit language which is a bit difficult to understand and translate for a common Ayurveda scholar. However, if understood and translated in an easier language his commentary "Nibandhasangraha" will prove to be a boon to every Ayurveda scholar.

So this review article presents a historical window of Dalhana's modifications over Sushrut Samhita. It is to constitute a good doctor who have knowledge of Samhita and the commentary constitutes an integral part.The Samhita without the commentary is like a bird with only one wing. I admit that I have nothing much to add as original matter except the concept of basic common plan given by Dalhana over Sushrut Samhita related to Sutrasthan Adhyaya no. 1 to 10.

\section{Aims and Objectives:}

1. To study the modifications of Dalhana over the Sushrut Samhita.

2. To evolve a logical scheme given by Dalhana.

3. To simplify the basic surgical approaches.

4. To compile all the basic concepts at a glance.

5. To study the scientific reasoning of Dalhana over the basic principles of clinical surgery.

6. To study the western surgical knowledge in parallel with ancient basic principles for better understanding.

7. To focus and enlighten the path based on Dalhana's principles for new research scholars.

\section{Materials and Methods}

Mentioned below are books studied line to line and chapter to chapter for present review of literature as these books are considered as most authentic classics in ancient and western surgical practice :

Sushrut Samhita, Sushrut commentary of Dalhana 'Nibandhasangraha', A system of surgical diagnosis, A concise textbook of surgery, A practical guide to operative surgery.

\section{Dalhana's Modifications}

Sushrutacharya had defined Shalyatantra as the branch which describes methods of removal of different kinds of foreign objects from the body like grass, wood, stone, metal, bone, hair, nails, pus exudation.(1) In addition to these foreign bodies, the commentator of Sushrut Samhita, Dalhanacharya has mentioned Mala also as a foreign body. In western surgical practice it is also observed that fecal material is one of the cause of obstruction.For example in obstructive acute appendicitis(2) and also in chronic constipation hard fecal material obstruct the lumen of intestine(3) due to which patient neither pass feces nor flatus and it requires removal of feces with various methods. From above 2 examples Mala is mentioned as foreign body in western surgical practice. It means Dalhana had keen observations in surgical practice and therefore he mentioned Mala as a Shalya (foreign body) in definition of Shalyatantra which requires Nirharana (extraction).

Tridosha Vata, Pitta and Kapha are the prime constituents of our body. In respect with Shalyatantra, Sushruta mentioned Rakta as an additional 4th Dosha(4). The commentator Dalhana explained the reason behind its acceptance as Shalyatantra is a branch which is more concerned with Vrana. He asserts that in the pathogenesis of Vrana, Rakta is a main constituent . Dalhana, therefore also supported Rakta as a 4th Dosha. If we compare this reasoning with western surgical discipline, it can be observed that blood and its constituents like haemoglobin, blood sugar level, serum 
bilirubin etc. play an important role in wound healing(5). When these constituents get abnormal they will be the prime cause of pathogenesis. This consideration of Rakta as a 4th Dosha in accordance with Shalyatantra is an apt example of the broad outlook that Dalhana had, thus making a great value addition to Sushruta's contributions.

Sushruta mentioned the methods of controlling diseases that are Samshodhana, Samshamana, Aahara and Vihara.To add to this, Dalhana explained two types of Samshodhana as Bahyashraya and Abhyantarashraya(6) .Dalhana also enlisted Shastra, Kshara, Agni and Pralepa under the heading of Bahyashraya Samshodhana and Vamana, Virechana, Aasthapana ,Raktamokshana under the heading of Abhyantarashraya Samshodhana. He further enlisted Aalep, Parishek, Avagaha, Abhyanga ,Shirobasti, Kavalagraha and Gandusha under the heading of Bahyashraya Samshamana and Pachana, Lekhana, Bruhan, Rasayana, Vajikaran etc. under Abhyantarashraya Samshaman. From the above description we can say that Dalhana gives advancement on Sushruta's quotation to understand the treatment modalities of Shalyatantra.

Sushruta mentioned Vrana Dhoopana by different Dhoopana Dravyas after Shodhana of Vrana. To add to this, Dalhana said that not only Vrana but also the Dhoopana of patient's clothes, beds, pillows, bed sheets, wards should be done(7). In western surgical practice we are using 2 methods i.e. aseptic and antiseptic(8) to prevent chances of infection. We know that aseptic methods are always better as compared to antiseptic methods. From the above Shalyatantra references it can therefore be observed that Sushruta focused on antiseptic methods whereas Dalhana throws light on antiseptic as well as aseptic precautions.

Sushruta mentioned light massage

over Hrudayadi Marmasthana with remaining Ghee after Dhoopana to restore the functions of body. Dalhana gives the reason behind it stating that "Massage helps to achieve proper functioning of vital parts and decreases uneasiness and anxiety of patient(9). From Dalhana's above explanation, Abhyanga can be advised to increase blood circulation of vital parts and to relieve uneasiness and anxiety of patient.

Sushruta mentioned five characeristics of Shastrakarmajanya Vrana as Aayata, Vishal, Suvibhakto, Nirashraya and Praptakalakruta(10). Dalhana elaborated the character Nirashraya as not involving any vital structure like Marma, Dhamani(artery), Sira(vein), Nadi(nerve), Lasika(lymphatics) etc.

In western surgical practice it is described that surgical incision should be parallel to those vital structures(11) to prevent complications like bleeding, lymphadenoma and nerve deformities. From the above explanation it is clear that Dalhana's view was more practical towards safe surgical procedures.

Sushruta mentioned that physician should remove bandage after 3 days in Hemant, Shishira and Vasanta rhutu and after 2 days in Sharad Grishma and Varsha Rhutu(12). Dalhana thought more deeply in relation to bandaging and mentioned that bandage should be removed and rebandage of the wound be done 2 times in a day in case of Pittaja Vrana in hot climate. He shows frequency of bandaging to avoid the chances of infection by removing previous soiled bandage. He also mentioned that chances of putrification are more due to hot climate in Sharad Grishma and Varsha Rhutu. In addition to support this explanation we can say that the Bala(immunity) is Heen(low) in these three season so chances of infection rate is high. Also in these Rhutus specifically in Varsha Rhutu wounds are very vulnerable for infection. In western surgical practice it is observed that we 
regularly and frequently do the dressing over infected and profuse discharging wound whereas dressing or bandaging is done on alternate days or less frequently in healthy granulated wound or less discharging wound.

Sushrutacharya mentioned different types of Yantra which are commonly prepared from metal or in their absence by those similar to it(13).To add to this Dalhana explains substitute like Danta, Shrunga, wood etc. Sushruta mentioned Alabu and Shrunga are useful in Raktamokshana procedure but it is strange to note that he does not furnish any details about it. Dalhana on the other hand gives details about the shape and size of Shrunga and Alabu and elaborating that Shrunga is 7 Angula broad, base is broad as Angushthamula and mouth opening must be equal to Mudaga. Alabu is 8 Angula broad, 4 Angula long, narrow mouth and coated with black soil(14).

Sushruta described Shadavidha Pariksha (Shabda, Sparsha, Roopa, Rasa, Gandha, Prashna) and also explained how to perform it to get detail history and thoroughly examination of disease from patient. Dalhana, the commentator also added that when any new disease co-exists and which is not included in literature (Anukta Vyadhi) can also be examined with the help of above mention Shadavidhapariksha(15). It is observed that in today's western medical practice these Shadavidhapariksha are found to be most important tool for diagnosis and so training of good doctor is therefore prepare him to use comprehensively. The above five senses by utilizing his ears, eyes, nose, hands, tongue, and interrogation(16) in a systematic way to gather useful history and physical science for arriving at correct diagnosis. We all are blessed with god gifted five senses which are our basic tools. From above explanation we came across the broad view of Sushruta and Dalhana about examination of patient and credit goes to both of them for explaining the methods of examination which is most important part in the diagnosis and prognosis of patient.

Sushruta mentioned that even easily curable diseases are difficult to be cured in kings, orthodox people, aged people, women,children etc.(17) Dalhana explained the reasoning behind it thus showing his keen clinical observation about patient and his diseases. According to him, children, elder people and frightful people cannot tolerate the Samshodhana procedure and high potency medicine. Due to shy nature of women they always relents the urge of Mala, Mutra and also refrain from giving proper history about the disease. Addicted people cannot follow the Pathya Apathya. So the Sukhasadhya Vyadhi becomes Dushchikitsya.

\section{Conclusion}

There is no doubt about Sushruta's, the father of ancient surgery has made notable contributions to the field of surgery. But the important and critically significant modifications of Dalhana the follower of Sushrut samhita was also a great clinician having knowledge of multiple sciences and who had studied the Samhita's from different angles to give the answers of many queries arising in the mind of a reader while reading the Sushrut Samhita.

Also it is concluded that this knowledge is very beneficial to every student and practitioner today and forever. Present article is a single candle of light which will help to give light from candle to candle and one day there will be brightness as like the sunlight in the form of knowledge for next generation.

\section{References}

1. Vd. Yadavji Trikamji Acharya; Sushrut Samhita of Sushruta with commentary of Dalhanacharya, chaukhamba surbharati prakashana, Varanasi,2003, pg.no. 3 
2. S.Das;a concise textbook of surgery; s. Das publication, Calcutta 4th edition, 2005, pg.no. 1003

3. S.Das; a concise textbook of surgery; s. Das publication, Calcutta 4th edition, 2005, pg.no. 982-983.

4. Vd. Yadavji Trikamji Acharya; Sushrut Samhita of Sushruta with commentary of Dalhanacharya, chaukhamba surbharati prakashana, Varanasi,2003, pg.no. 6

5. S.Das; a concise textbook of surgery; $s$. Das publication, Calcutta 4th edition, 2005, pg.no. 6-7.

6. Vd. Yadavji Trikamji Acharya; Sushrut Samhita of Sushruta with commentary of Dalhanacharya, chaukhamba surbharati prakashana, Varanasi,2003, pg.no. 7

7. Vd. Yadavji Trikamji Acharya; Sushrut Samhita of Sushruta with commentary of Dalhanacharya, chaukhamba surbharati prakashana, Varanasi,2003, pg.no. 21

8. S.Das;a practical guide to operative surgery; s. Das publication, Calcutta 4th edition, 1999, pg.no. 17.

9. Vd. Yadavji Trikamji Acharya; Sushrut Samhita of Sushruta with commentary of Dalhanacharya, chaukhamba surbharati prakashana, Varanasi,2003, pg.no. 21

10. Vd. Yadavji Trikamji Acharya; Sushrut Samhita of Sushruta with commentary of Dalhanacharya, chaukhamba surbharati prakashana, Varanasi,2003, pg.no. 20

11. S.Das;a practical guide to operative surgery; s. Das publication, Calcutta 4th edition, 1999, pg.no. 23

12. Vd. Yadavji Trikamji Acharya; Sushrut Samhita of Sushruta with commentary of Dalhanacharya, chaukhamba surbharati prakashana, Varanasi,2003, pg.no. 23

13. Vd. Yadavji Trikamji Acharya; Sushrut Samhita of Sushruta with commentary of Dalhanacharya, chaukhamba surbharati prakashana, Varanasi,2003, pg.no. 31

14. Vd. Yadavji Trikamji Acharya; Sushrut Samhita of Sushruta with commentary of Dalhanacharya, chaukhamba surbharati prakashana, Varanasi,2003, pg.no. 56

15. Vd. Yadavji Trikamji Acharya; Sushrut Samhita of Sushruta with commentary of Dalhanacharya, chaukhamba surbharati prakashana, Varanasi,2003, pg.no. 43

16. Prof. T. N. Patel; a system of surgical diagnosis; Jaypee brothers medical publishers Ltd. New Delhi, 3rd edition, 1998; pg.no.1

17. Vd. Yadavji Trikamji Acharya; Sushrut Samhita of Sushruta with commentary of Dalhanacharya, chaukhamba surbharati prakashana, Varanasi,2003, pg.no. 44 